\title{
Considering biomass growth and regeneration in the optimisation of biomass supply chains
}

\author{
Annelies De Meyer ${ }^{\mathrm{a}}$, Dirk Cattrysse ${ }^{\mathrm{b}}$, Jos Van Orshoven $^{\mathrm{a}}$ \\ ${ }^{a}$ Department of Earth and Environmental Sciences, Division Forest, Nature and Landscape, KU Leuven, Celestijnenlaan 200E, 3001 Leuven, \\ Belgium \\ ${ }^{b}$ Department of Mechanical Engineering, Centre for Industrial Management / Traffic E Infrastructure, KU Leuven, Celestijnenlaan 300, 3001 \\ Leuven, Belgium
}

\begin{abstract}
High logistics and handling costs are among the factors that prevent the bioenergy industry from making a greater contribution to the present energy market. This paper presents t-OPTIMASS, a multiperiod mixed-integer linear programming model to optimise strategic and tactical decisions in all kinds of biomass supply chains. The model takes into account the main characteristics of biomass supply chains, i.e.geographical fragmentation and temporal availability of biomass, seasonal energy demand and changing biomass characteristics due to handling operations. Unlike existing models, t-OPTIMASS also considers the growth and regeneration of biomass to determine the optimal harvesting moment(s).

t-OPTIMASS is demonstrated based on the use of grass from nature reserves and road verges to feed the currently available wet anaerobic digesters or potential dry anaerobic digesters in Limburg (Belgium). A sensitivity analysis gives insight in the influence of uncertainty in biomass productivity and the effect of energy input related to extra products. The decision process is strongly driven by the biomass requirements at the conversion facility implying that biomass should be delivered with characteristics that fit these requirements without intensive pre-treatment. In combination with the need for gradual installation of facilities, this endorses the need to include biomass growth and regeneration in optimisation.
\end{abstract}

Keywords: multiperiod MILP, bioenergy, growth cycle, regeneration, seasonal availability, OPTIMASS

\section{Introduction}

To meet the world's ever increasing energy consumption, biomass is considered as an attractive feedstock for renewable energy because it is abundantly present and, in comparison to most other renewable energy sources, it can be stored to generate different forms of energy (i.e. electricity, heat and biofuels) on demand $(1 ; 2)$. However, biomass is still a source of energy that is generally underutilised due to uncertainties related to weather variability and market conditions (3) and to barriers induced by the complex supply chain (4;3). An increasing number of research papers report on the combination of supply chain management and operational research in the field of bioenergy systems to tackle the challenge to develop a sustainable bioenergy industry considering the interrelated decisions within the supply chain, the complex hierarchy in decision making and the role of each actor within the chain $(1 ; 3 ; 5 ; 6 ; 7$; 8). Most models have been developed to (economically) optimise long-term, usually investment intensive decisions pertaining to the design of the biomass supply network (e.g., sourcing of biomass, choice of capacity, technology and location of storage, pre-treatment and conversion facilities) (8). These spatial optimisation models consider the spatial fragmentation of the biomass production units and its typical characteristics such as a high moisture content, low bulk density and low heating value.

Furthermore, the seasonal availability of biomass makes the biomass supply chain different from those typically addressed in supply chain management (2). This introduces the challenge to address the temporal availability of biomass, the possibly conflicting temporal energy demand and the temporally constant feeding requirement of the conversion facilities (2). Multiperiod MILP models have been proposed to optimise the strategic and tactical plans resulting in the minimal overall chain cost throughout the planning horizon of one year to tune the seasonal availability 
of biomass to meet the conflicting, seasonal energy demand $(9 ; 10 ; 11 ; 12 ; 13 ; 14 ; 15 ; 16)$. These models consider the seasonal biomass availability and energy demand by defining the quantity of available biomass and the energy demand in each time period (usually months) as a fixed value. These models highlight the gradual installation of storage and conversion capacities over time highlighting the need for the incorporation of time into strategic decision making (17). Similar multiperiod MILP models have been presented to minimise the overall chain cost within a planning horizon of multiple years $(17 ; 18 ; 19 ; 20 ; 21)$. In contrast with the models that consider the monthly availability of biomass, these models divide their planning horizon into 1 year time periods. They provide the opportunity to create long-term schedules (mainly plant and harvest) of perennial crops such as Miscanthus, Short Rotation Coppice, Switchgrass (15).

Apart from its seasonal availability, biomass is also characterised by a growth cycle. This implies that, within the growth season, a new growth cycle starts after harvest enabling multiple harvesting moments throughout the planning horizon. So, the moment of harvest does not only determine the availability and characteristics of biomass at that moment, but also influences the availability and characteristics of tomorrow's biomass. To use biomass as a sustainable, renewable source of energy, the required constant supply of biomass must balance the accretion of biomass in the field (22). Also, the moment of harvesting should be adapted to fit best the requirements of storage and conversion facilities considering the required continuous supply at the conversion facility, the changing energy demand, statutory harvesting moments, etc. This suggests that the growth and regeneration of biomass is decisive in the design and management of the supply chain. However, to the best of our knowledge, these issues are not incorporated in the published models optimising biomass supply chains strategically and/or tactically. Only recently, Yu et al. (2014) consider forest regeneration, the cutting cycle and biomass degradation during storage in an operational planning model to weekly assign harvesting teams and to allocate the biomass flows resulting in a minimal cost over the 1-year planning horizon (22).

This paper describes the expansion of the spatially oriented mixed integer linear programming (MILP) model, OPTIMASS (23), to consider the growth and regeneration of biomass in the strategic/tactical decision process (Section 2). OPTIMASS has been selected because the model embraces the upstream biomass supply chain in a comprehensive way which makes it applicable to all kinds of biomass supply chains. Furthermore, OPTIMASS takes into account changes in product characteristics due to handling operations. A similar approach can be applied to define changes in characteristics due to growth or regeneration. In comparison to OPTIMASS as a spatial optimisation model, this spatio-temporal expansion enables the definition of the optimal harvesting moment and the gradual installation of handling facilities. This paper illustrates the functionalities and possibilities of the model by the application to a supply chain based on biomass derived from low input high diversity (LIHD) systems to anaerobic digesters in the Limburg province (Belgium) (Section 3). OPTIMASS is applied to determine the optimal configuration of the supply chain resulting in the maximal net energy output considering (1) the currently present wet anaerobic digesters and (2) potential dry anaerobic digesters (Section 4). Furthermore, a sensitivity analysis is performed to determine the impact on the supply chain of (1) changes in biomass production and (2) changes in the energy input from the use of extra products (Section 5). These analyses result in an evaluation of the behaviour of OPTIMASS as spatio-temporal optimisation model and the definition of opportunities for its further elaboration (Section 6).

\section{Materials and Methods}

\subsection{OPTIMASS}

The deterministic, static, multiechelon, multiproduct mixed integer linear programming (MILP) model, OPTIMASS, is meant to optimise the strategic (i.e. design) and tactical (i.e. logistics planning) decisions in all kinds of biomass supply chains based on the maximal net energy output, maximal revenue and/or minimal global warming potential. To embrace biomass supply chains in a comprehensive way, OPTIMASS is based on the results of a generic cradle-to-gate analysis of the upstream biomass supply chain highlighting six key operations from the point of harvesting raw biomass materials to the delivery of the biomass to the conversion facility: i.e. biomass production, harvest, collection, pre-treatment, storage and conversion to bioenergy (Figure 1) (24).

OPTIMASS approaches the problem as a multi-stage capacitated facility location planning problem (25) in which at each facility the characteristics of the biomass product can change due to handling operations. This translates into integer variables defining the strategic decisions (cfr. boxes in figure 1) and continuous variables defining the tactical 
decisions (cfr. arrows in figure 1). Unlike (most) other models, OPTIMASS takes into account changes in product type (and characteristics) due to handling operations. Therefore, transformation coefficients are created that define the transition from one product type to another. In a similar way, OPTIMASS considers the re-injection of by-products from the conversion process in the biomass supply chain. A complete description is given in De Meyer et al. (in review). In that paper, the analysis of OPTIMASS for sensitivity to changes in biomass production and in energy demand highlights the need for a multiperiod optimisation approach to define a network that can cope with these variations in time (23).

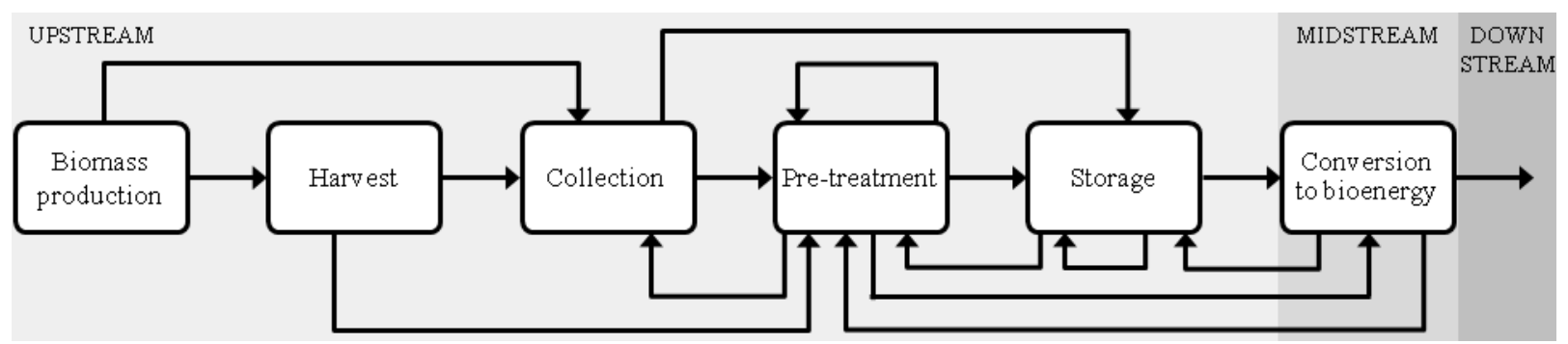

Figure 1: High level process model of OPTIMASS representing the sequence of operations in the biomass supply chain $(\mathrm{a}$ box $=$ operation; arrow = product flow) (8)

\subsection{Upgrade to a spatio-temporal MILP model considering biomass growth and regeneration}

The multiperiod problem can be seen as a network consisting of a number of layers in which each layer represents a time period in which OPTIMASS, as presented in section 2.1, is applicable (Figure 2). In each time period t, the arcs that connect the nodes represent product flow in that period (solid arrow in figure 2). To support optimisation of the biomass network over a certain planning horizon consisting of multiple time periods, two consecutive time periods $(\mathrm{t}$ and $\mathrm{t}+1)$ must be linked. Therefore, inventory arcs are introduced at storage sites $(\mathrm{j}, \mathrm{l})$ and conversion sites $(\mathrm{k}, \mathrm{m})$ fine-tuning the transfer of biomass from one time period to the other (dashed arrows in figure 2).

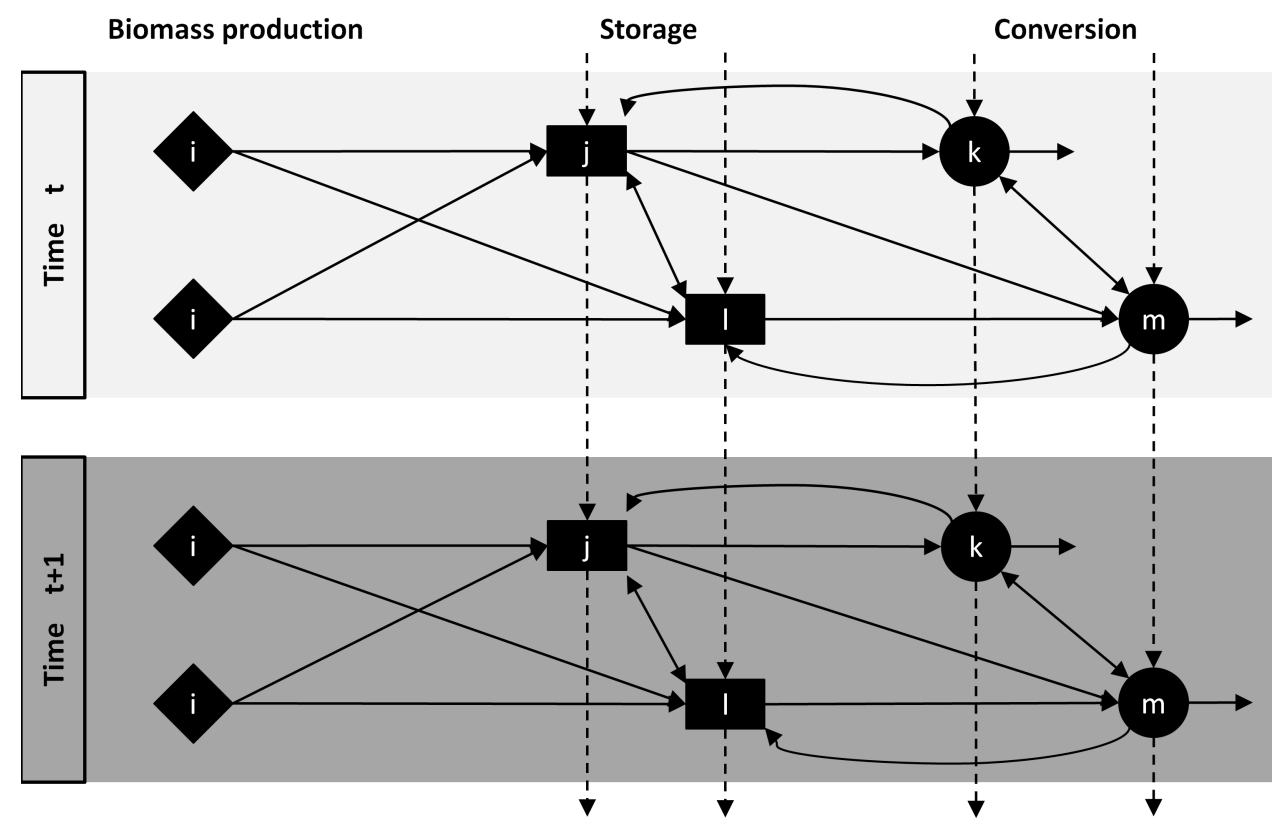

Figure 2: Simplified representation of the multiperiod approach considering the product flow between biomass production sites (i), storage sites $(\mathrm{j}, \mathrm{l})$ and conversion sites $(\mathrm{k}, \mathrm{m})$ (solid arrows) and between time periods (dashed arrows) 


\subsubsection{Regulating biomass growth and regeneration}

To consider biomass growth and regeneration, different product types must be defined to represent biomass in each of the possible growth stages in terms of the typical characteristics (e.g., harvestable biomass production, biogas production). In the first time period, the maximum available quantity of each product type $f$ at each biomass production site i (S U P max $x_{i t}^{f}$ ) is defined by constraint (1a). This constraint relies on the data on the available area of each biomass type at each biomass production site $\left(A R E A_{i}^{f}\right)$. This implies that one biomass production site can contain biomass of different types and growth stages. In the subsequent time periods, the maximum available quantity of each product type $\mathrm{f}$ at each biomass production site $\mathrm{i}\left(S \operatorname{UPmax}_{i t}^{f}\right)$ depends on the quantity of product type $\mathrm{f}$ harvested in the previous period $\left(s N_{i t-1}^{f}\right)$ and the quantity of product type f not harvested in the previous period $\left(s N H_{i t-1}^{f}\right)$ (constraint (1b)). Transformation coefficients define the changes in product type (and therefore growth stage) due to the harvest $\left(\gamma_{H}^{f, r}\right)$ and due to the growth $\left(\gamma_{N H}^{f, r}\right)$ considering the change in harvestable biomass production. Constraint (2) ensures that the mass balance within one time period is maintained. To ensure the readability of the paper, the explanation of the symbols is given in Appendix A.

$$
\begin{gathered}
\text { SUPmax } \max _{i t}^{f}= \begin{cases}A R E A_{i}^{f} \cdot H B P^{f} & \forall i \in I, f \in F, t=1 \quad \text { (a) } \\
\sum_{r}\left(s H_{i t-1}^{r} \cdot \gamma_{H}^{r f}\right)+\sum_{r}\left(s N H_{i t-1}^{r} \cdot \gamma_{N H}^{r f}\right) & \forall i \in I, r \in F, t>1 \quad \text { (b) }\end{cases} \\
\quad S u p_{\text {max } i t}^{f}=s H_{i t}^{f}+s N H_{i t}^{f} \quad \forall i \in I, f \in F, t \in T
\end{gathered}
$$

\subsubsection{Temporal energy demand}

Similar to the multiperiod models described in the introduction, the energy demand in each period (t) is a fixed value $\left(D_{t}^{o}\right)$. Constraint (3) ensures that in each time period the total demand for each type of bioenergy (e.g., heat, electricity) is met. The production of an energy surplus is allowed by constraint (4). The explanation of the symbols is given in Appendix A.

$$
\begin{gathered}
\text { Esurplus }_{t}^{o}=\sum_{k \in K} \sum_{c \in C}\left(E_{k t}^{c o}\right)-D_{t}^{o} \quad \forall o \in O, t \in T \\
\text { Esurplus }_{t}^{o} \leqslant Q^{o} \cdot D_{t}^{o} \quad \forall o \in O, t \in T
\end{gathered}
$$

\subsubsection{Connection between time periods}

The inventory arcs (dashed arrows in figure 2) create the bridge between two subsequent time periods. These inventory arcs are represented by inventory variables which define the amount of product type $f$ transferred from one period to the next at the storage facility $\left(I_{j t}^{f s}\right)$ and conversion facility $\left(I_{k t}^{f c}\right)$. In constraints (5) and (6), the inventory is defined by the inventory of the previous period $\left(I_{j t-1}^{f s}\right.$ and $\left.I_{k t-1}^{f c}\right)$, the quantity of product delivered at the storage and conversion facility $\left(X_{i n j t}^{f s}\right.$ and $X_{c t}^{f k}$ ) minus the quantity of product departing from the storage facility $\left(X_{\text {out } j t}^{f s}\right.$ ) or converted at the conversion facility $\left(C_{c t}^{f k}\right)$. In addition, pre-treatment operations can occur at these facilities leading to changes of product characteristics. So, the mass balance considers the quantity of product type $f$ entering a pretreatment operation at that facility $\left(X_{j t}^{f s p}\right.$ and $\left.X_{k t}^{f c p}\right)$ and the quantity of the product type created after pre-treatment $\left(P_{j t}^{s p f}\right.$ and $\left.P_{k t}^{c p f}\right)$. To consider the supply chain in a circular way, the inventory of the final period (T) is available in the first period ( $t=1)$ (constraint (5a) and constraint (6a)). A steady state regime is assumed which implies that the harvestable biomass production and energy demand change according to the same seasonal pattern every year. However, this cyclicity assumption is not required and can be removed by taking out out the variables $I_{j T}^{f s}$ and $I_{c T}^{f k}$ from equations (5a) and (6a). The explanation of the symbols is given in Appendix A.

$$
I_{j t}^{f s}= \begin{cases}I_{j T}^{f s}+X_{i n j t}^{f s}-\sum_{p} X_{i n j t}^{f s p}+\sum_{p} P_{j t}^{s p f}-\frac{X_{\text {out } j t}^{f s}}{1-\Delta^{s}} & \forall f \in F, j \in J, s \in S, t=1 \\ I_{j t-1}^{f s}+X_{i n j t}^{f s}-\sum_{p} X_{i n j t}^{f s p}+\sum_{p} P_{j t}^{s p f}-\frac{X_{\text {out } j t}^{f s}}{1-\Delta^{s}} & \forall f \in F, j \in J, s \in S, t>1\end{cases}
$$




$$
I_{c t}^{f k}= \begin{cases}I_{c T}^{f k}+X_{c t}^{f k}-\sum_{p} X_{k t}^{f c p}+\sum_{p} P_{k t}^{c p f}-C_{c t}^{f k} \quad \forall f \in F, k \in K, c \in C, t \in T \\ I_{c t-1}^{f k}+X_{c t}^{f k}-\sum_{p} X_{k t}^{f c p}+\sum_{p} P_{k t}^{c p f}-C_{c t}^{f k} \quad \forall f \in F, k \in K, c \in C, t>1\end{cases}
$$

\section{Use case description}

Anaerobic digesters can handle various types of biomass and waste (26). In most cases, co-digestion of several product types even leads to superior digestion efficiencies $(26 ; 27)$. To not compete with food crops in agricultural land usage, a potential promising role is reserved for biomass from low input high diversity (LIHD) systems such as (semi-) natural grasslands, small landscape elements, etc. $(28 ; 29 ; 30 ; 31 ; 32 ; 33 ; 34 ; 35 ; 36 ; 37 ; 38 ; 39)$. Therefore, the functionalities and behaviour of the spatio-temporal t-OPTIMASS are demonstrated based on the potential of mesotrophic grass from nature reserves and grass from road verges to feed anaerobic digesters in the Limburg province $\left(2422 \mathrm{~km}^{2}\right)$ (Belgium) (Figure 4). The possible operations in the supply chain are presented in figure 3 . The attributes and attribute values are defined for each product and operation type (Table B.3). Data and assumptions are retrieved from databases such as EcoInvent (40) or peer-reviewed literature and expert opinions.

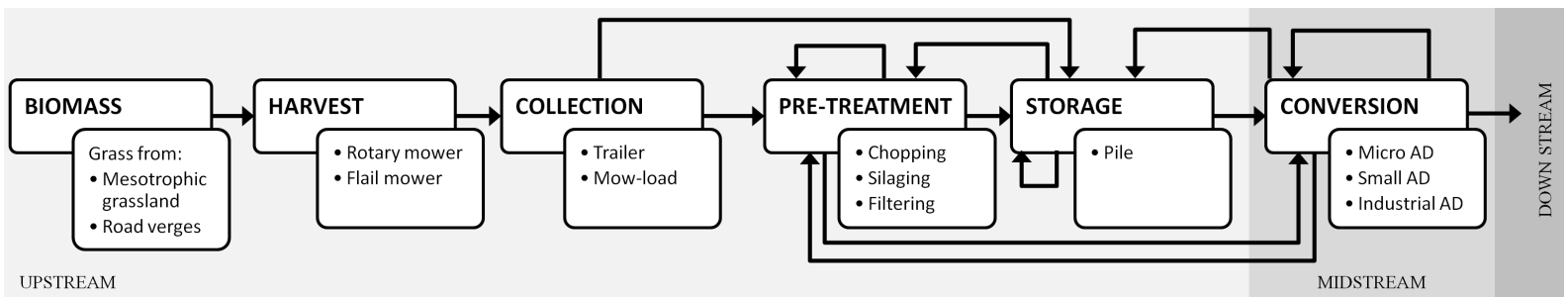

Figure 3: High level process model of the studied LIHD-to-bioenergy supply chain (AD = Anaerobic digester)

The locations and corresponding areas of the mesotrophic grasslands and road verges are derived from the biological valuation map of Limburg (Belgium) (41) represented by a grid of $1 \mathrm{~km}$ by $1 \mathrm{~km}$ resolution as described in Van Meerbeek et al. (submitted). To allow the graphic display of the results in an orderly manner, the $1 \mathrm{~km} \mathrm{by} 1 \mathrm{~km}$ grid is resampled to a $5 \mathrm{~km} \times 5 \mathrm{~km}$ grid in which the area of the biomass sites equals the sum of the areas of the 1 $\mathrm{km}$ by $1 \mathrm{~km}$ grid cells that fall within the $5 \mathrm{~km}$ by $5 \mathrm{~km}$ cell (Figure 4). In Belgium, the road verge decree of 1984 (Bermbesluit 27/06/84) limits the possible moments to harvest to one mowing period after June 15th and a second mowing period after September 15th. This implies that the 1-year time horizon can be divided into 5 time periods: January to May (TP1), June - July (TP2), August (TP3), September - October (TP4) and November - December (TP5) (Figure 5). So, grass from mesotrophic grasslands and road verges can only be mown in TP2, in TP4 or both (TP24). The model considers the time-dependent harvestable biomass production and biogas potential to define the optimal harvesting moment $(42 ; 39 ; 29)$ (Table B.2).

To process the biomass, all 13 wet anaerobic digesters currently available in Limburg are considered (Figure 4). Based on the capacity, three types of digesters are distinguished: i.e. 8 micro anaerobic digesters (MAD), 4 farm scale anaerobic digesters (FAD) and 1 industrial anaerobic digester (IAD) (Table B.3). The produced biogas is fed into a combined heat and power (CHP) installation to generate heat and electricity. It is assumed that the anaerobic digesters must generate at least $90 \%$ of their annual electricity capacity. This results in an electricity demand profile as presented in figure 5. The demand corresponds to the needs of \pm 17000 households (considering an average electricity consumption of $3500 \mathrm{kWh}$ per household) which is about $5 \%$ of the households in Limburg. It is assumed that the wet anaerobic digesters process organic household waste (0-20\%), maize (10-20\%) and pig slurry (50-80 \%) (Table B.2). For these "extra products", OPTIMASS determines the optimal quantity of product used in each conversion facility considering a certain energy input related to the use of the extra product, the maximum available quantity of the product and several requirements in the conversion facility. However, the supply chain of these products is not optimised. LIHD biomass, of which the supply chain is optimised in this use case, is considered to replace maize or organic household waste with a required minimum of $5 \%$ to an allowed maximum of $20 \%$ of the total conversion mixture (28). 


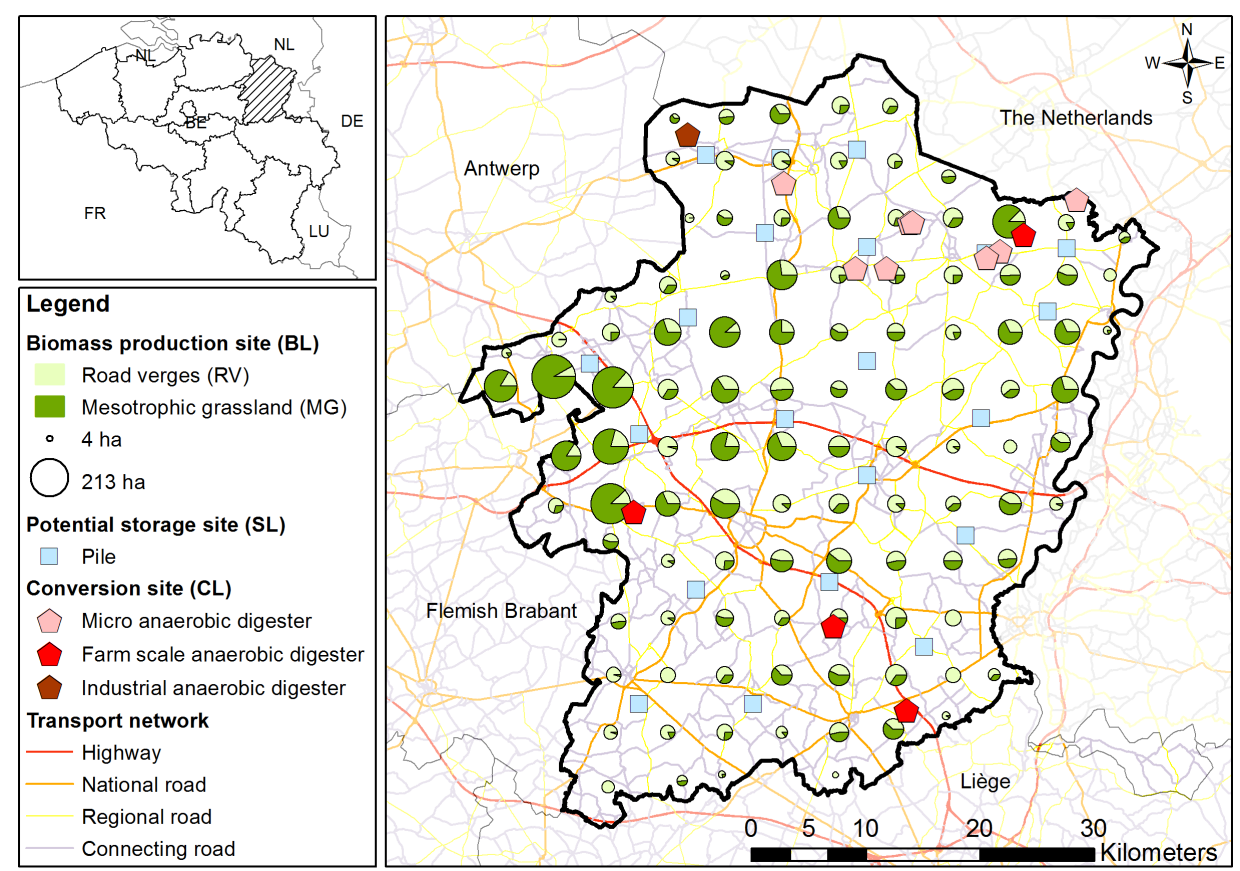

Figure 4: Considered bioenergy network in the Limburg province (without the municipality of Voeren)

To deal with the peak flow of harvested biomass in TP2 and TP4, long-term storage is needed $(44 ; 29)$. The preferred form of storage is ensilaging, since grass can be preserved with minimal loss (29) and the treatment is proven to have relatively little effect on specific biogas yield (44). Since biomass from mesotrophic grasslands can only be harvested with the rotary mower, chopping of silage prior to digestion is required. This is not the case for grass from road verges because the harvesting operation with the flail mower results in biomass with sufficiently small particle size. However, grass from road verges is usually contaminated with litter and sand causing all kinds of problems in the digester. Therefore, filtering and washing of grass from road verges prior to ensilaging or digestion is required (42). Due to a lack of real-world data, the location (and capacity) of storage sites is fictitious in this use case. Twenty-one storage sites are defined considering the location of highway access points, conversion sites and biomass production sites (Figure 4). The selected number of storage sites is a trade-off between the clear display of the results and the illustration of the functionalities. A storage site houses an open-air pile with a capacity of $1500 \mathrm{~m}^{3}$.

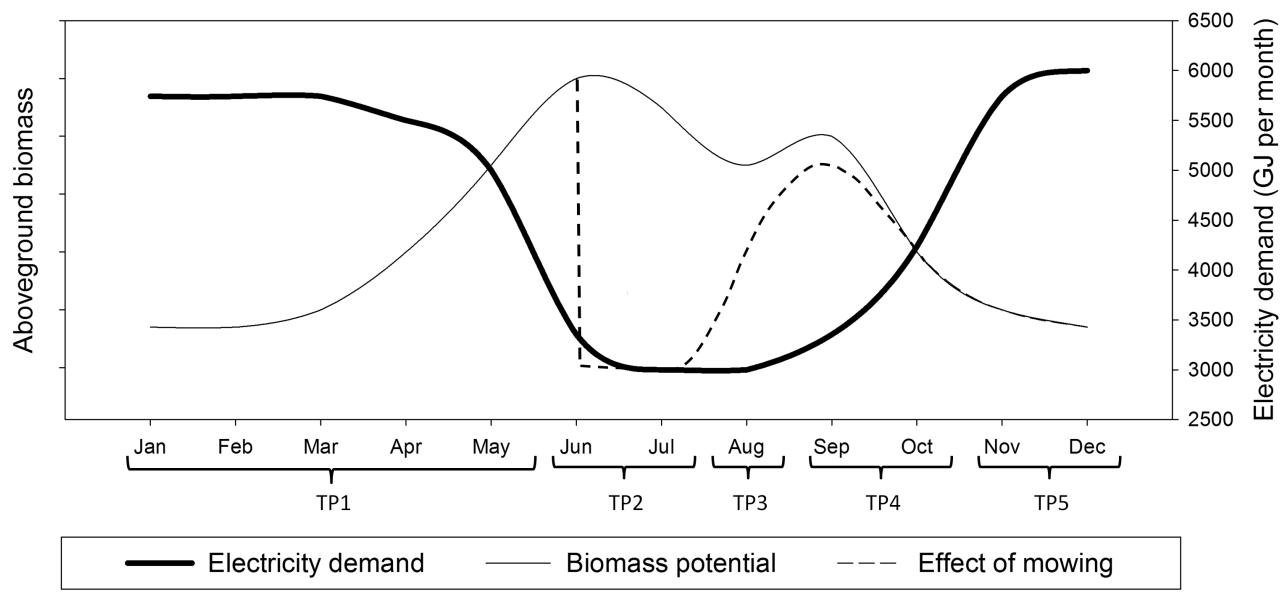

Figure 5: Monthly changes in biomass availability and energy demand (based on (43)) 
The real-world transport distances are retrieved from the Navstreet database (45). For truck transport, the shortest path between sites $\left(d_{x y}^{z}\right)$ are determined considering the driving directions and restrictions from Navstreet. For transport by tractor, it is assumed that tractors can not access the highway, but are allowed to access all other roads.

\section{Scenario analysis}

\subsection{Scenario 1: Optimising the use of the current infrastructure}

This scenario (1a) considers the LIHD biomass supply chain including the currently present wet anaerobic digesters. This implies that the binary variables $\left(Y_{k t}^{c}\right)$ are pre-set to 0 or 1 to define the (non-)existence of a conversion type at each conversion site in each period. The resulting optimal supply chain is presented in figure 6 in which 14 (out of 21) storage facilities are opened by OPTIMASS. In this supply chain, 220043 GJ of electricity and 305417 GJ of heat are produced per year. Around $42 \%$ of the total energy output is needed to perform all operations in the chain (Scenario 1a in table 1).

\begin{tabular}{|l} 
Legend \\
Biomass production site (BL) \\
Road verges (RV) \\
Mesotrophic grassland (MG) \\
4 ha \\
213 ha \\
Potential storage site (SL) \\
$\quad$ Pile \\
Conversion site (CL) \\
Micro anaerobic digester \\
Farm scale anaerobic digester \\
Industrial anaerobic digester \\
Transport BL-CL \\
RV TP2 \\
RV TP4 \\
RV TP24 \\
Transport SL-CL \\
\hline Silage MG TP2 \\
\hline Silage MG TP24 \\
\hline MG TP2 \\
+ MG TP24 \\
\end{tabular}

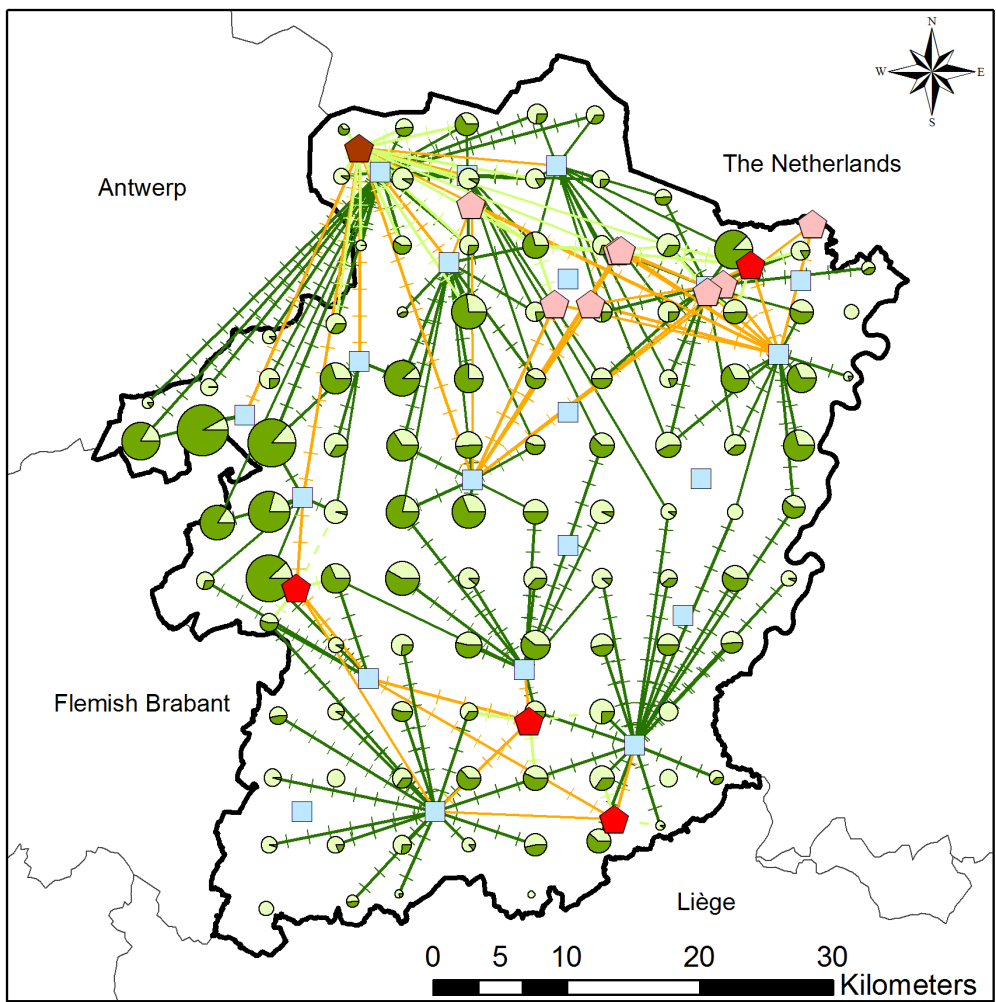

Figure 6: Result scenario 1: Optimising the use of the current infrastructure - Presentation of all biomass flows throughout the one-year time horizon

The biomass mixture converted in the anaerobic digesters consists of $80 \%$ pig slurry, $15 \%$ maize and $5 \%$ grass from nature reserves or road verges. The high quantity of pig slurry relates to the required high moisture content of the biomass mixture (between $80 \%$ and $95 \%$ ) and the relatively low energy input when manure is used. In addition, the model chooses to use maize in stead of organic household waste due to the higher biogas potential of maize. Not more grass from LIHD systems is used than the required 5\% which is mainly related to its high energy input compared to the manure and maize (i.e. energy input of extra products). In the mixture of LIHD biomass, $83 \%$ consists of grass from mesotrophic grassland and only $17 \%$ of grass from road verges. The biomass from mesotrophic grasslands is harvested by rotary mower (as required) and stored in one of the 14 opened storage locations where it is ensilaged (Figure 6). After chopping, this silage is converted to biogas (mainly) during the non-harvesting periods (TP1, TP3 
and TP5) (Figure 7). Analysis indicates that all available grass from mesotrophic grasslands is harvested in both TP2 and TP4. To meet the required 5\% LIHD biomass in the conversion mixture, grass from road verges (harvested by flail mower) is added to the mixture only during harvesting periods because grass from road verges does not require ensilaging prior to digestion (Figure 7).

Scenario 1a states that grass from mesotrophic grassland is more preferred than grass from road verges. This is mainly due to the fact that grass from mesotrophic grasslands does not need filtering. This conclusion is endorsed by the analysis of scenario $1 \mathrm{~b}$ in which all LIHD biomass available in TP2 and TP4 must be harvested (Scenario 1b in table 1). This forces the increase of LIHD in the conversion mixture from the minimum required $5 \%$ to $8.3 \%$. The net energy output decreases with $\pm 4 \%$, a.o. due to a tripling of the energy input related to filtering of the grass from road verges.

In both scenarios (1a and 1b), all LIHD biomass is transported by tractor due to the small study area and corresponding short distances between facilities. This implies that the tractor with higher energy input per kilometre but avoiding energy input for transshipment is more beneficial than the truck with lower energy input per kilometre and higher energy input for transshipment. Previous analysis has pointed out that the tipping point between transport by tractor and transport by truck is about $80 \mathrm{~km}(23)$.

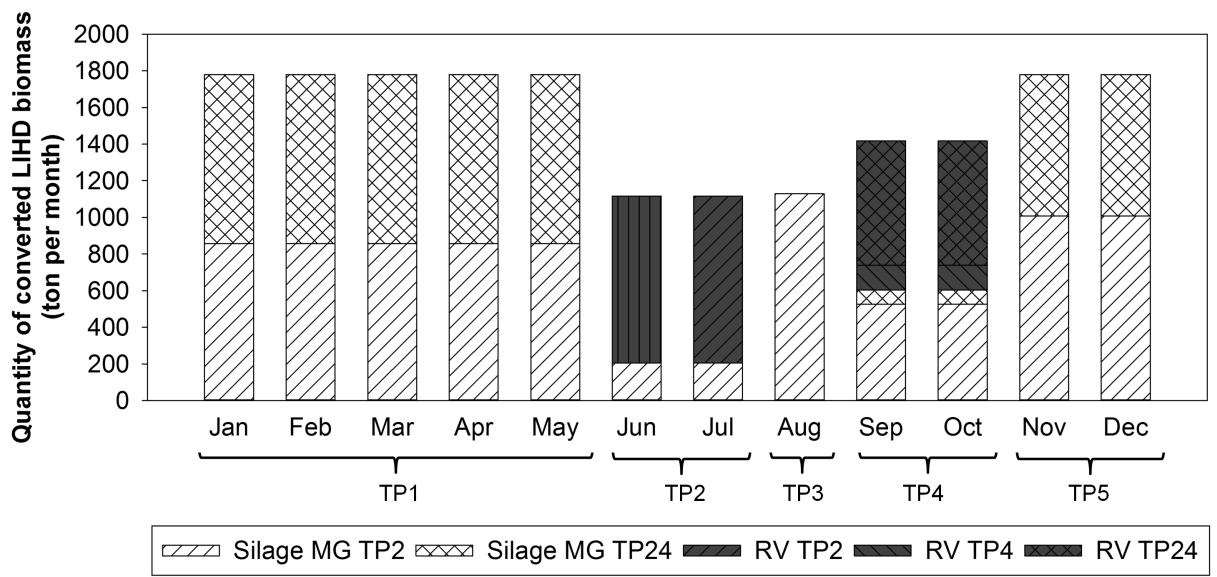

Figure 7: Result scenario 1: Optimising the use of the current infrastructure

Table 1: Summary of the energy demand (GJ), gross energy output (GJ), energy input (GJ) and corresponding net energy output (GJ)

\begin{tabular}{l|rrr}
\hline & SCENARIO 1A & SCENARIO 1B & SCENARIO 2 \\
\hline Gross energy output & 525459.7 & 525477.6 & 525530.7 \\
Energy input (LIHD): & & & \\
$\quad$ Transport & 9484.1 & 13144.7 & 8632.6 \\
$\quad$ Harvest & 1481.7 & 2309.1 & 1773.6 \\
Collection & 4176.5 & 5170.2 & 3531.9 \\
$\quad$ Pre-treatment & 6478.9 & 18313.1 & 488.7 \\
Storage & 2493.8 & 2381.3 & 1050.0 \\
$\quad$ Conversion & 101116.8 & 101116.8 & 101116.8 \\
Energy input extra product & 96249.0 & 90958.3 & 115093.4 \\
\hline Net energy output & 303979.0 & 292084.1 & 293843.6 \\
\hline
\end{tabular}$$
\text { (1) }
$$

\section{So far, dry aters}

So far, dry anaerobic digestion in Flanders is an exception (42). However, different studies indicate that dry anaerobic digesters are ideal for the digestion of grass in combination with organic household waste (42). To evaluate the potential to process grass from LIHD systems in dry anaerobic digesters, in this scenario all wet anaerobic digesters 
(from scenario 1) are converted to dry anaerobic digesters of the same capacity. The moisture content of the biomass mixture in the digester must be between 60 and $80 \%$ and that only maize and organic household waste are included as extra products (42). By default, a dry digester for organic household waste is equipped with a pre-treatment to separate interfering substances such as litter, metal, etc. (42). Therefore, filtering of grass from road verges prior to the feeding into the digester is not longer required (42). In this supply chain, $220043 \mathrm{GJ}$ of electricity and $305488 \mathrm{GJ}$ of heat are produced. Around $44 \%$ of the total energy output is needed to perform all operations in the chain (Scenario 2 in table 1).

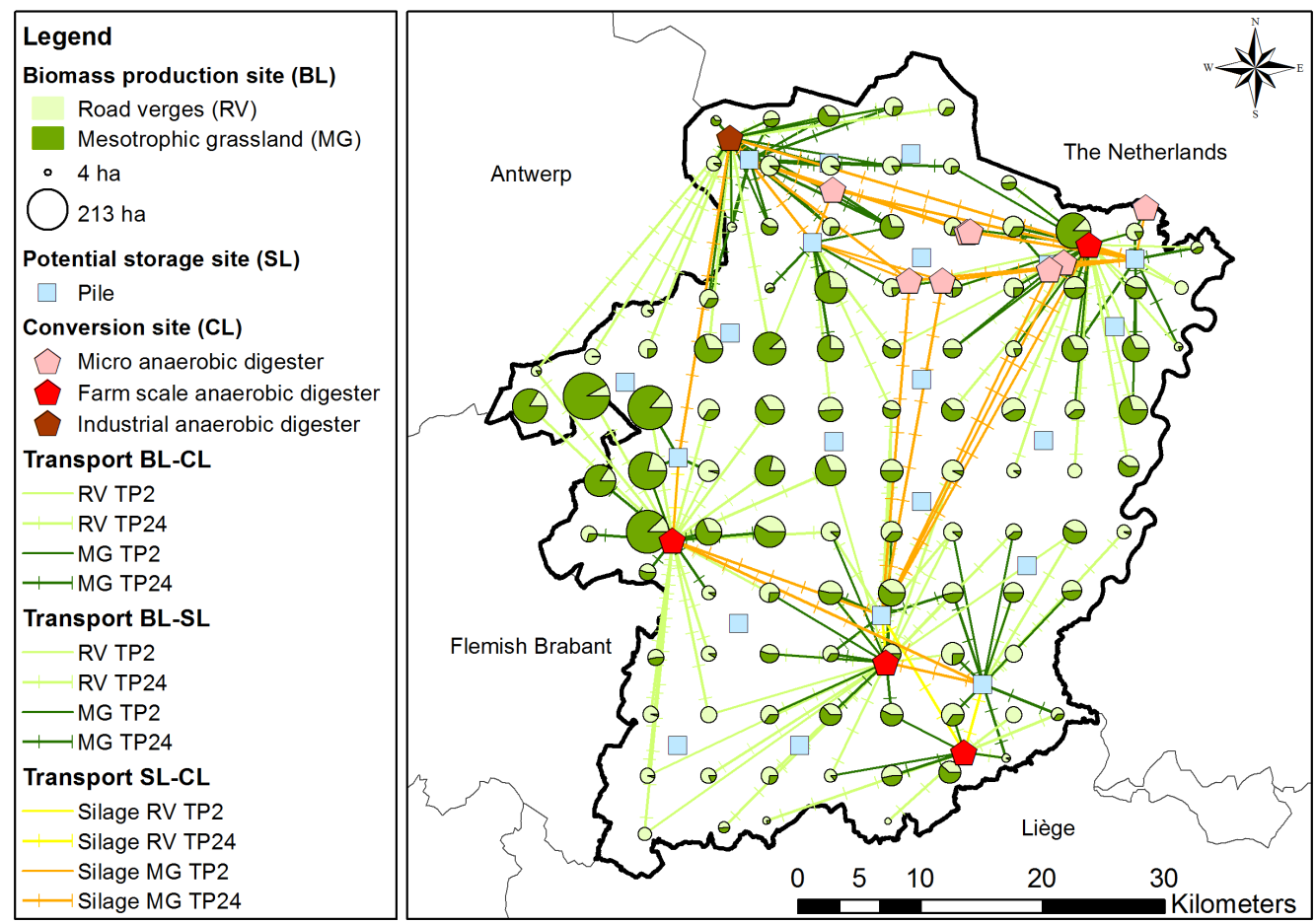

Figure 8: Result scenario 2: The potential of dry anaerobic digesters - Presentation of all biomass flows throughout a one-year time horizon

At first sight, this scenario is less efficient than scenario 1 with wet anaerobic digesters. However, the lower net energy output is directly related to the energy input needed for organic household waste which is much higher than the one of pig slurry. So, after excluding the energy needed for the extra products, it is clear that the use of dry anaerobic digesters results in a more efficient chain. The quantity of LIHD biomass rises with $37 \%$ (Figure 8 ) while the total energy input for LIHD usage drops with $36 \%$ (Table 1) mainly due to the unnecessity of the filter requirement. Also, grass from mesotrophic grasslands does not need to be chopped and can be digested without prior ensilaging. On the other hand, LIHD biomass is mainly used in the period in which it is harvested reducing the energy related to the storage operations (only 5 out of 21 storages are opened) (Figure 8).

While in scenario 1a, all mesotrophic grassland has been harvested and only 17\% of the LIHD biomass emanates from road verges, this is reversed when using dry anaerobic digesters (with 63\% from road verges and $37 \%$ from mesotrophic grassland) (Figure 8). In comparison to scenario 1a, silage from mesotrophic grassland is transported over larger distances. This is mainly due to the fact that a fixed energy input is attributed to the opening of a storage facility. Therefore, the number of used storage facilities is minimised to store the needed silage.

Further analysis indicates that in the harvesting periods the use of biomass from the LIHD systems is more beneficial than using organic household waste (42\% in TP2 and 23\% in TP4) (Figure 9). However, during the non-harvesting periods, its share is only the required $5 \%$ of the biomass mixture. This implies that more energy is needed to pre-treat and store the LIHD biomass compared to the use of organic household waste. 


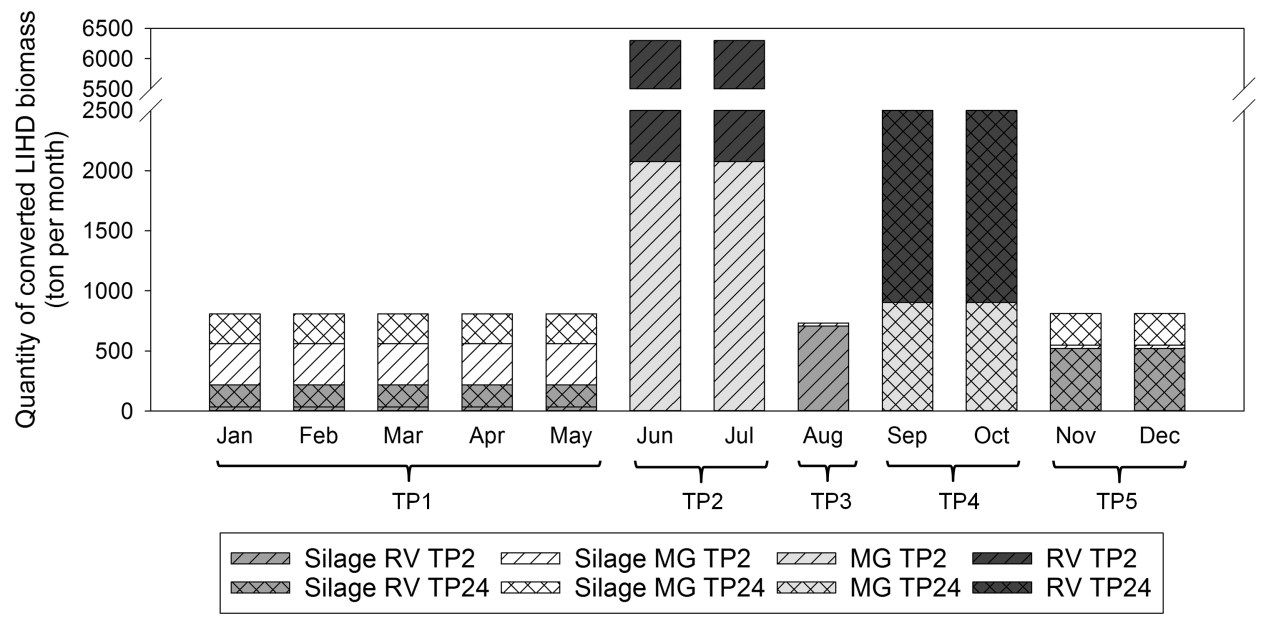

Figure 9: Result scenario 2: The potential of dry anaerobic digesters

\section{Sensitivity analysis}

\subsection{Sensitivity to changes in harvestable biomass production}

Uncertainty induced by a.o. weather conditions (e.g., long winter, early spring, long summer) can affect the available quantity of biomass during the allowed harvesting moments (TP2 and TP4). Considering scenario 1a, the effect of this uncertainty has been investigated by varying the harvestable biomass production $\left(H B P_{t}^{f}\right)$ in TP2 (June/July) and subsequently in TP4 (September/October) between the lowest harvestable biomass production resulting in a feasible solution without changing constraints or other parameters and a doubling of the harvestable biomass production defined in table B.2.

Figure 10 indicates that in both cases the net energy output increases when more LIHD biomass is available. Since the deviation in gross energy output is small due to the fixed demand constraint, this implies that the energy input in the chain decreases. This trend is more pronounced when the availability of biomass is limited $(<100 \%)$. If less biomass is available in the first harvesting period (Figure 10a), the requirement of min $5 \%$ of the conversion mixture can be met with biomass harvested in the second harvesting period. In the first feasible solution (13\% of the harvestable biomass production) all biomass available in both harvesting periods is harvested. The net energy output is small due to high energy need for extra products and long-term storage. In case of f.e. a late spring or short summer, less biomass is available in the second harvesting period (TP4). Therefore, almost all storage facilities are opened to store grass from nature reserves and road verges harvested in TP2 to meet the required biomass supply in the subsequent periods.

As the available biomass production increases, the share of grass from road verges decreases (from 26\% (TP2) and $39 \%$ (TP4) to $0 \%$ in both cases) and more mesotrophic grass is harvested in TP2 and in TP4 to be stored as silage to guarantee year-round supply of biomass to the digester. Since the biogas production from mesotrophic grass is higher and the energy use for its pre-treatment is lower in comparison to grass from road verges, the share of silage from mesotrophic grassland harvested in harvesting period 1 rises to the detriment of grass from road verges. Although the quantity of ensilaged grass increases, the total energy related to pre-treatment in the chain decreases due to the high energy input for the filtering of grass from road verges. In the harvesting periods, grass from road verges is directly transported to the anaerobic digesters, while mesotrophic grass and the surplus of grass from road verges is ensilaged to be digested during the non-harvesting periods. Furthermore, the energy input related to the use of extra products also decreases since more LIHD biomass becomes available in the areas close to the anaerobic digesters. The net energy output reaches an equilibrium when more biomass is available ( $>100 \%)$. The main explanation is that the total maximum storage capacity is reached which limits the amount of silage to be produced and stored in the supply chain. On the other hand, the constraints defining the moisture content requirements in the conversion facility limit the amount of biomass allowed in the conversion process. 


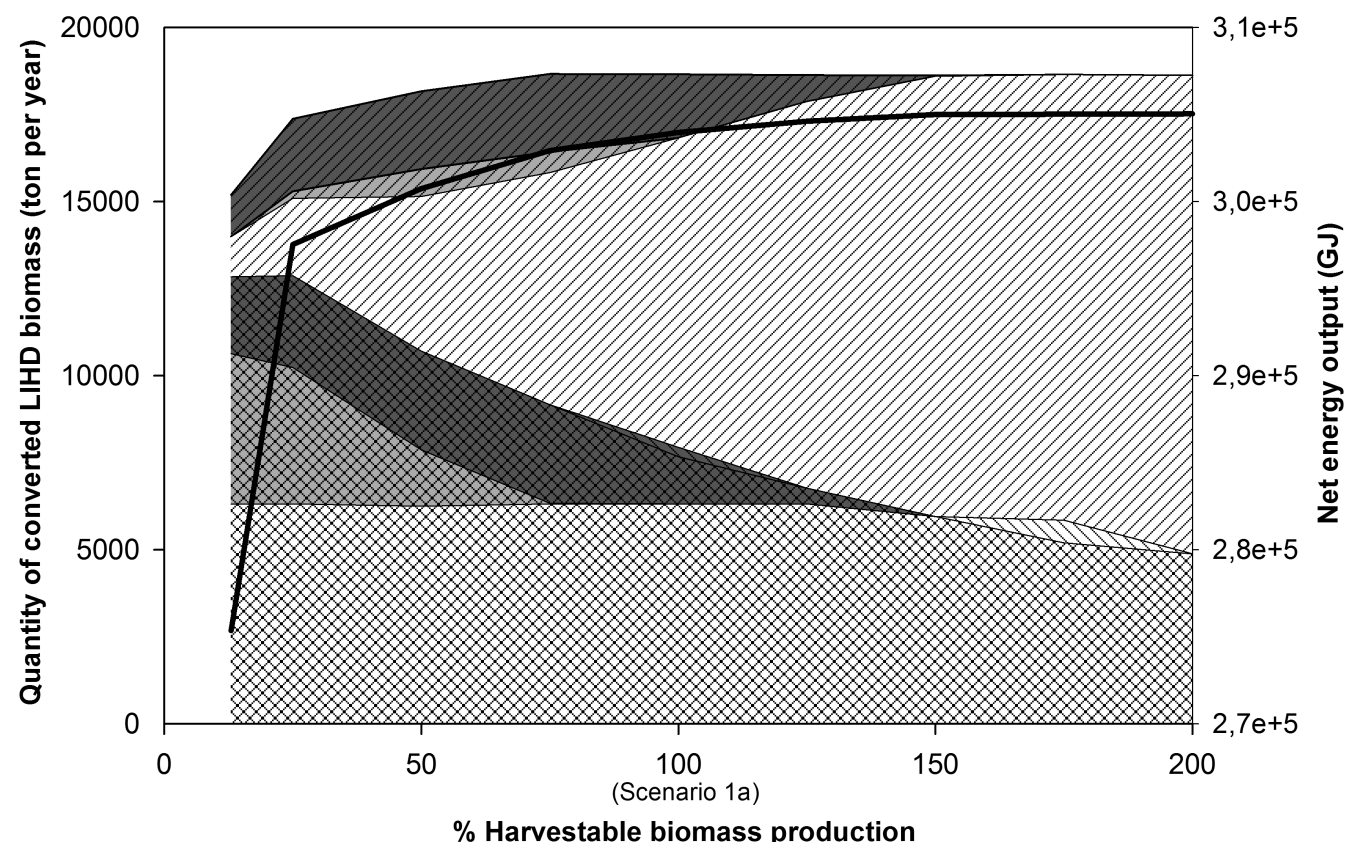

$\%$ Harvestable biomass production

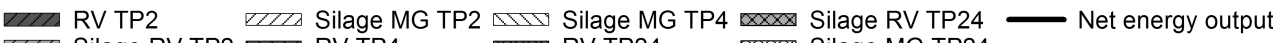
IIIT Silage RV TP2 $\quad$ RV TP4

(a) Summary of the sensitivity of the LIHD biomass converted in the chain and of the net energy output to changes in harvestable biomass production in the first harvesting period (TP2)

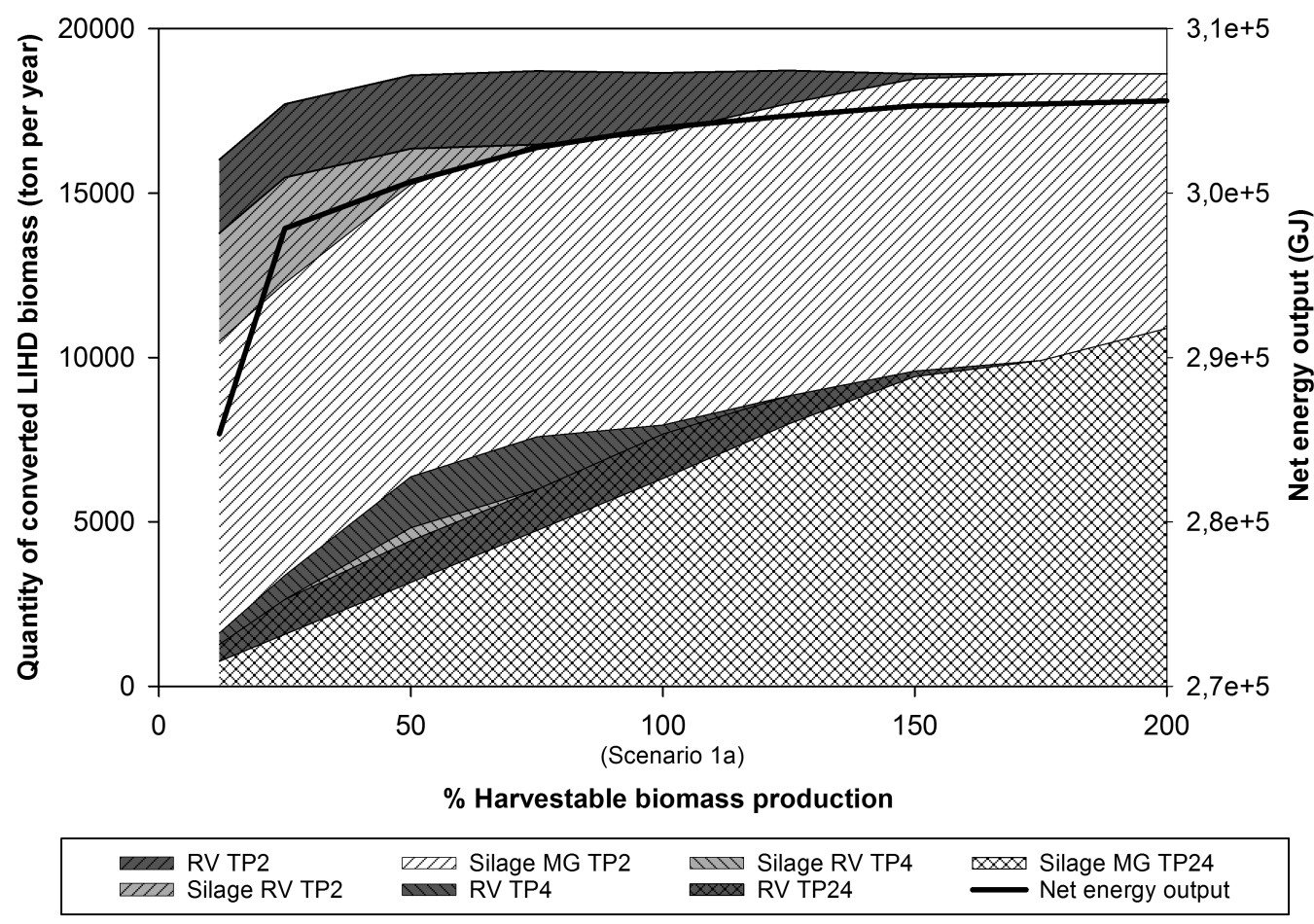

(b) Summary of the sensitivity of the LIHD biomass converted in the chain and of the net energy output to changes in harvestable biomass production in the second harvesting period (TP4)

Figure 10: Results of the sensitivity analysis investigating the influence of changes in harvestable biomass production 


\subsection{Sensitivity to energy input related to extra product}

The results of the studied scenarios point out that a large share of the energy input is related to the use of the (required) extra products (i.e. maize, organic household waste and pig slurry). Since an exact value for this energy input could not be found in literature and thus had to be estimated, this section investigates the effect of changes in the energy input related to the extra product. Therefore, the energy input defined in table B.3 has been multiplied with factors ranging between 0 and 15 (Figure 11) based on scenario 1a.

Figure 11 indicates that until a doubling of the energy input related to the extra products (A), the use of extra products is more beneficial than the use of LIHD biomass. The share of LIHD biomass in the conversion mixture of the anaerobic digesters only is at the minimum required 5\%. Most LIHD biomass converted in the digesters originates from the mesotrophic grasslands and these areas are harvested in TP2 and TP4. The share of grass from road verges is small, but increases as the energy input for extra products increases. Also here, the quantity of grass from road verges is reduced due to the high energy input related to the required filtering treatment. From point (A), the share of LIHD biomass in the total conversion mixture rises until it reaches a steady state of $7.9 \%$ (B). This rise relates to the increase of grass from mesotrophic grasslands harvested for the second time (MG TP24). In addition, the share of grass from road verges harvested in the first harvesting period (TP2) grows. First, this grass is immediately converted in the anaerobic digester. However, reaching the steady state at point (B), most grass from road verges is being ensilaged. The main driver for this decision is the higher moisture content of silage in comparison to grass. After point (B), the biomass mixture remains unchanged.

The analysis of the energy inputs needed for the different operations indicates that a steady increase is attributed to the harvest, collection, storage and transport of the LIHD biomass. This increase is directly related to the rising quantity of LIHD biomass used in the chain. However, the transition towards the use of grass from road verges and the increase of ensilaging mainly induces a much higher rise in the energy input related to the pre-treatment operations in the supply chain. This induces a decrease of the gross energy output from $526000 \mathrm{JG}$ at point (A) to a steady state of $\pm 506000 \mathrm{GJ}$ at point $(\mathrm{B})$

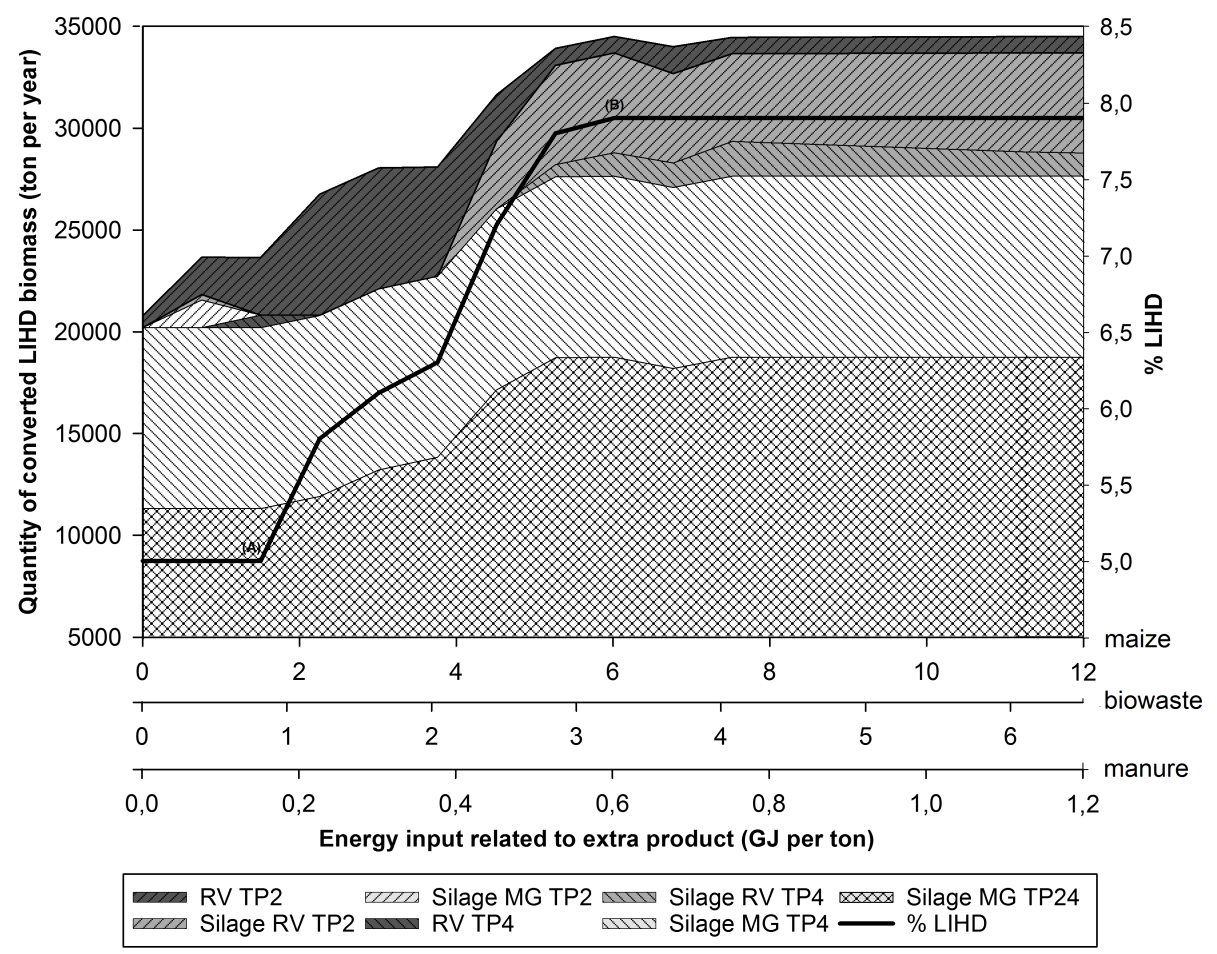

Figure 11: Results of the sensitivity analysis investigating the influence of the energy input related to the use of extra products on the LIHD biomass converted in the chain and on the net energy output 


\section{Discussion and conclusion}

This paper presents the expansion of OPTIMASS towards a multiperiod mixed integer linear programming model, t-OPTIMASS, to optimise strategic and tactical decisions in all kinds of biomass supply chains based on the maximal net energy output. Therefore, the model takes into account the main characteristics of the biomass supply chain, i.e. geographical fragmentation and availability of biomass resources, growth and regeneration of biomass, seasonal energy demand, changing biomass characteristics due to handling operations and growth. Unlike existing multiperiod models, t-OPTIMASS considers the temporal cyclicity or regeneration in the production of biomass to determine the optimal harvesting moment(s) throughout the time horizon considering the changing energy demand and the requirement of continuous supply of biomass to the digesters.

The scenario and sensitivity analyses based in the LIHD-to-digester supply chain indicate that storage facilities are indispensable to deal with the temporal availability of biomass, the conflicting temporal energy demand and the required constant feeding of the conversion facilities. Furthermore, the decision process is strongly driven by the requirements (moisture content, particle size, etc.) of the conversion facilities. The feeding rate defines the minimum required and maximum allowed quantity of biomass that can be processed by the conversion facilities and this has a clear influence on the allocation pattern. The regulation of biomass mixture to be converted at the facility defines what kind of biomass is delivered to the conversion facility. The moisture content and particle size requirements define in which format the biomass must be delivered. These requirements impose the need to include changes in biomass characteristics due to handling operations and the growth stage at the moment of harvesting. In addition, the analyses state that it is more beneficial to use biomass with characteristics that fit the requirements of the conversion facilities. This reduces the cost for pre-treatment operations and an overload of storage needs. As stated in previous studies $(42 ; 46 ; 47 ; 48)$, dry anaerobic digestion of LIHD biomass in combination with organic household waste is more beneficial than digestion in wet anaerobic digesters. The requirements of the dry anaerobic digesters better fit the characteristics of grass from nature reserves and road verges and do not required antecedent pre-treatment operations such as chopping and filtering. Furthermore, the use of multiple products enables the use of each biomass type in a more optimal way reducing the supply chain costs as the inflow of biomass is spread over the year and storage costs are reduced. The analysis of the current situation (Scenario 1) highlights that the share of LIHD biomass in the conversion mixture is limited to the minimum required 5\%. Analysis has pointed out that this limitation relates directly to the estimated energy input needed to use the extra products (Section 5.2). To make a well-founded statement about the value of LIHD biomass in bioenergy production, analysis with more reliable, quantitative values addressing the energy input (especially related to the use of extra products) is needed. In this paper the main goal is to illustrate the potential of t-OPTIMASS. The results indicate a direction of change, but do not intend to present the most realistic values. Section 5.2 indicates that a small energy input related to extra products stimulates the use of LIHD biomass.

By the incorporation of changes in biomass characteristics due to handling operations and the growth and regeneration of biomass in the decision process, t-OPTIMASS is able to optimise the supply chain ensuring the sustainable use of biomass which becomes decisive when modern bioenergy supply scales up significantly. Furthermore, the generic approach enables the applicability of t-OPTIMASS to all kinds of biomass supply chains. This is illustrated by its application to the supply chain of poplar wood to saw mills and paper mills in Belgium. In this case, the constant supply of poplar must balance the accretion in the field considering the growth of poplar, a minimum required regeneration period and a time horizon of 30 year. Besides dealing with annual and perennial crops, t-OPTIMASS can also be applied to optimise the supply chain of biomass with seasonal availability of biomass but lacking growth and regeneration. This is studied in an on-going use case in which the supply of organic household waste to a composting facility in Belgium is optimised and another use case in which the processing chain of sludge from municipal wastewater treatment plants is studied (49).

t-OPTIMASS can be seen as a base model to which use case specific constraints or specific spatial and temporal variables can be added. For example, OPTIMASS considers product loss during storage as a fixed fraction of biomass and defines a specified biogas reduction (8\%) due to ensilaging independent of the storage duration. However, these values are fixed and are independent of the length of the storage period. To improve the decisions considering storage duration and sustainable use of biomass, deteriorating inventory models can be included in t-OPTIMASS. Also, a temporal capacity of extra products can be easily added to t-OPTIMASS to include the use of multiple products available in different periods. Furthermore, t-OPTIMASS, as described in this paper, assumes a steady state regime (Equation (5a) and (6a)) which implies that the harvestable biomass production and energy demand change according to the 
same seasonal pattern every year. To consider influence of e.g. climate change in decision making, t-OPTIMASS can be extended to consider the this effect on these patterns. However, due to the complexity of the model and the large number of integer variables (a.o. due to the incorporation of pre-treatment operations), computation times can increase significantly. This requires a trade-off between making the model more realistic and the tolerated computational time.

\section{Acknowledgements}

This research is funded by funded by a Ph.D. grant of the Agency for Innovation by Science and Technology (IWT) in Flanders, Belgium.

\section{References}

[1] F. Mafakheri, F. Nasiri, Modelling of biomass-to-energy supply chain operations: Applications, challenges and research directions, Energy Policy 67 (2014) 116-126.

[2] A. A. Rentizelas, A. J. Tolis, I. P. Tatsiopoulos, Logistics issues of biomass: The storage problem and the multi-biomass supply chain, Renewable and Sustainable Energy Reviews 13 (2009) 887-894.

[3] N. Shabani, S. Akhtari, T. Sowlati, Value chain optimization of forest biomass for bioenergy production: A review, Renewable and Sustainable Energy Reviews 28 (1998) 299-311.

[4] S. Gold, S. Seuring, Supply chain and logistics issues of bio-energy production, Journal of Cleaner Production 19 (2011) $32-42$.

[5] B. Sharma, R. Ingalls, C. Jones, A. Khanchi, Biomass supply chain design and analysis: Basis, overview, modelling, challenges, and future, Renewable and Sustainable Energy Reviews 24 (2013) 608-627.

[6] I. Awudu, J. Zhang, Uncertainties and sustainability concepts in biofuel supply chain management: A review, Renewable and Sustainable Energy Reviews 16 (2012) 1359-1368.

[7] E. Iakovou, A. Karagiannidis, D. Vlachos, A. Toka, A. Malamakis, Waste biomass-to-energy supply chain management: a critical synthesis, Waste management 30 (2010) 1860-70.

[8] A. De Meyer, D. Cattrysse, J. Rasinmäki, J. Van Orshoven, Methods to optimise the design and management of biomass-for-bioenergy supply chains: A review, Renewable and Sustainable Energy Reviews 31 (2014) 657-670.

[9] H. An, W. E. Wilhelm, S. W. Searcy, Biofuel and petroleum-based fuel supply chain research: A literature review, Biomass and Bioenergy 35 (2011) 3763-3774.

[10] A. Dunnett, C. Adjiman, N. Shah, Biomass to heat supply chains - Applications of process optimization, Trans IChemE Part B 85 (2007) 419-429.

[11] S. D. Eksioğlu, A. Acharya, L. E. Leightley, S. Arora, Analyzing the design and management of biomass-to-biorefinery supply chain, Computers \& Industrial Engineering 57 (2009) 1342-1352.

[12] P. Flisberg, M. Frisk, M. Rönnqvist, FuelOpt: a decision support system for forest fuel logistics, Journal of the Operational Research Society (2012) 1-13.

[13] H. Gunnarsson, M. Rönnqvist, Solving a multi-period supply chain problem for a pulp company using heuristics An application to Södra Cell AB, International Journal Production Economics 116 (2008) 75-94.

[14] G. Tembo, F. M. Epplin, R. L. Huhnke, Analyzing the design and management of biomass-to-biorefinery supply chain, Journal of Agricultural and Resource Economics 28 (2003) 611-633.

[15] X. Zhu, X. Li, Q. Yao, Y. Chen, Challenges and models in supporting logistics system design for dedicated-biomass-based bioenergy industry, Bioresource Technology 102 (2011) 1344-1351.

[16] F. You, B. Wang, Life Cycle Optimization of Biomass-to-Liquid Supply Chains with Distributed - Centralized Processing Networks, Industrial and Engineering Chemistry Research 50 (2011) 10102-10127.

[17] G. Walther, A. Schatka, T. S. Spengler, Design of regional production networks for second generation synthetic bio-fuel A case study in Northern Germany, European Journal of Operational Research 218 (2012) 280-292.

[18] Y. Huang, C.-W. Chen, Y. Fan, Multistage optimization of the supply chains of biofuels, Transportation Research Part E: Logistics and Transportation Review 46 (2010) 820-830.

[19] U. D. Tursun, S. Kang, H. Önal, Y. Ouyang, J. Scheffran, Optimal Biorefinery Locations and Transportation Network for the Future Biofuels Industry in Illinois, in: Proceedings of the October 15 and 16, 2008 Conference, St. Louis, Missouri - Environmental and rural development impacts - Transition to a bio economy, 2008, pp. 149-166.

[20] S. Wang, A. Hastings, P. Smith, An optimization model for energy crop supply, Global Change Biology Bioenergy 4 (2012) 88-95.

[21] F. D. Mele, A. M. Kostin, G. Guillén-Gosálbez, L. Jiménez, Multiobjective Model for More Sustainable Fuel Supply Chains. A Case Study of the Sugar Cane Industry in Argentina, Industrial and Engineering Chemistry Research 50 (2011) 4939-4958.

[22] Z. Yu, C. Klein, J. Wang, Multi Period operational planning in woody biomass systems, in: Proceedings of the 2014 Industrial and Systems Engineering Research Conference, Nashville, Tennessee, 2014

[23] A. De Meyer, D. Cattrysse, J. Van Orshoven, Generic mathematical model to optimise strategic decisions in biomass-for-bioenergy supply chains (OPTIMASS), European Journal of Operational Research (in review).

[24] A. De Meyer, J. Almeida, W. Achten, B. Muys, D. Cattrysse, J. Van Orshoven, Incorporating life cycle impact assessment in mathematical model to optimize strategic decisions in biomass-for-bioenergy supply chains, in: Proceedings from the LCA XIII International Conference 'Fulfilling LCA's Promise', October 1-3, 2013, Orlando, FL, United states, 2013, pp. 24-33.

[25] S. Melkote, M. Daskin, Capacitated facility location/network design problems, European Journal of Operational Research 129 (2001) 481495. 
[26] L. Appels, J. Lauwers, J. Degrève, L. Helsen, B. Lievens, K. Willems, J. Van Impe, R. Dewil, Anaerobic digestion in global bio-energy production: Potential and research challenges, Renewable and Sustainable Energy Reviews 15 (2011) $4295-4301$.

[27] P. Gerin, F. Vliegen, J.-M. Jossart, Energy and $\mathrm{CO}_{2}$ balance of maize and grass as energy crops for anaerobic digestion, Bioresource Technology 99 (2008) 2620-2627.

[28] S. De Moor, F. Velghe, I. Wierinck, E. Michels, B. Ryckaert, A. De Vocht, W. Verbeke, E. Meers, Feasibility of grass co-digestion in an agricultural digester, influence on process parameters and residue composition, Bioresource Technology 150 (2013) $187-194$.

[29] A. Prochnow, M. Heiermann, M. Plöchl, B. Linke, C. Idler, T. Amon, P. Hobbs, Bioenergy from permanent grassland - A review: 1. Biogas, Bioresource Technology 100 (2009) 4931-4944.

[30] W. Hohenstein, L. Wright, Biomass energy production in the United States: an overview, Biomass and Bioenergy 6 (1994) $161-173$.

[31] S. McLaughlin, D. de la Torre Urgate, C. Garten, L. Lynd, M. Sanderson, V. Tolbert, D. Wolf, High-value renewable energy from prairie grasses, Environmental Science and Technology 36 (2002) 2122-2129.

[32] J. Murphy, N. Power, An argument for using biomethane generated from grass as a biofuel in Ireland, Biomass and Bioenergy 33 (2008) 504-512.

[33] K. Vogel, Energy production from forages (or American agriculture: back to the future), Journal of Soil and Water Conservation 51 (1996) $137-139$.

[34] G. Caron, L. Kuiper, R. van den Broek, Landschapsstroom - Energetische benutting van biomassa uit natuurterreinen (Landscape stream Energetic utilisation of biomass from natural areas), Tech. rep., Ecofys BV (2003).

[35] D. Tilman, J. Hill, C. Lehman, Carbon-negative biofuels from low-input high-diversity grassland biomass, Science 314 (2006) 1598-1600.

[36] K. Bervoets, Nieuwe perspectieven voor beheerresten (New perspectives for management residues), Tech. rep., Natuurpunt in association with the Flemish Government (2008).

[37] B. Velázquez-Martí, E. Fernández-González, I. López-Cortés, D. Salazar-Hernández, Quantification of the residual biomass obtained from pruning of trees in mediterranean almond groves, Renewable energy 36 (2011) 621-626.

[38] K. Van Meerbeek, J. Van Beek, L. Bellings, W. Aertsen, B. Muys, B. Hermy, Quantification and Prediction of Biomass Yield of Temperate Low-Input High-Diversity Ecosystems, Bioenergy Research 7 (2014) 1120-1130.

[39] K. Van Meerbeek, L. Appels, R. Dewil, J. Van Beek, L. Bellings, K. Liebert, B. Muys, B. Hermy, Energy potential for combustion and anaerobic digestion of biomass from low-input high-diversity systems in conservation areas, GCB Bioenergy.

[40] Ecoinvent Centre, ecoinvent data v2.0. ecoinvent reports No. 1-25, Tech. rep., Swiss Centre for Life Cycle Inventories, Dübendorf, Switzerland (2007). URL www .ecoinvent.org

[41] Instituut voor Natuurbehoud, Biologische waarderingskaart van het Vlaamse Gewest. Geïntegreerde versie van de recentst beschikbare karteringen $(56 \%$ BWK, versie 2 en $44 \%$ BWK, versie 1) (Biological valuation map of Flanders. Integrated version of the most recent surveys (56\% BVM, version 2 and 44\% BVM, version 1)) (2001).

[42] F. Velghe, P. Magielse, I. Moorkens, S. De Meester, Bermg(r)as - Droge anaerobe vergisting van bermgras, in combinatie met GFT+, Tech. rep., OWS nv, IGEAN, VITO, UGent (2014).

[43] P. De Becker, Hoofdstuk 6 graslanden, ruigten en natuurbeheer, in: M. Hermy, G. De Blust, M. Slootmaekers (Eds.), Natuurbeheer, Uitg. Davidsfonds i.s.m. Argus vzw, Natuurpunt vzw and IN, Leuven, 2004, pp. 190-219.

[44] J. McEniry, E. Allen, J. Murphy, P. O’Kiely, Grass for biogas production: The impact of silage fermentation characteristics on methane yield in two contrasting biomethane potential test systems, Renewable Energy 63 (2014) 524-530.

[45] NAVTEQ, Navstreets (native) vector 2011.3 (2011)

[46] Inverde, Graskracht, Eindrapport (Power of grass, Final report), Inverde, Brussel, 2012.

[47] K. Schelfhout, P. Loncke, Gentegreerde verwerkingsmogelijkheden (inclusief energetische valorisatie) van bermmaaisel, Tech. rep., OVAM (2009).

[48] IEE GR3, Ats and best practices for grass residue collection and valorization, report of the iee gr3 grass as a green gas resource: Energy from landscapes by promoting the use of grass residues as a renewable energy resource, Tech. rep., Co-funded by the Intelligent Energy Europe Programme of the European Union (2014).

[49] A. De Meyer, D. Cattrysse, P. Ostermeyer, J. Van Orshoven, Implementation of OPTIMASS to optimise municipal wastewater sludge processing chains: Proof of concept, Waste management (submitted).

[50] R. Guisson, M. Van Dael, Eindrapport ecp-case belgisch limburg (final report ecp-case belgian limburg), Tech. rep., VITO and UHasselt (2013).

[51] K. Van Meerbeek, S. Ottoy, A. De Meyer, T. Van Schaeybroeck, J. Van Orshoven, B. Muys, B. Hermy, The bioenergy potential of conservation areas and roadsides for biogas in an urbanized region, Applied Energy.

[52] Bokhorst, J and Ter Berg, C, Abstract Mest \& compost (Abstract Manure and compost) (accessed on 01-07-2014). URL www . bodemacademie.nl/documenten/94.pdf

[53] JansenWijhe, Praktijkervaring vergisting natuurmaaisel in limburg, grass to green gas, Tech. rep., Workshop Inverde (2014).

[54] B. Mattheeuws, Mogelijkheden van vergisting voor de production van biogas (2007).

[55] R. Melse, D. Starmans, N. Verdoes, Mestverwerking varkenshouderij. Mestscheiding en microfiltratie, Dirven te Someren (Manure processing of pig husbandry. Manure separation and microfiltration, Dirven at Someren), Tech. rep., Praktijkonderzoek veehouderij, WUR (2002).

[56] R. Suurs, Long distance bioenergy logistics. An assessment of costs and energy, Tech. Rep. January, University of Utrecht, The Netherlands (2002).

[57] P. Lubbe, C. Archer, E. Whitehead, Guide to machinery costs 2012/13, Tech. rep., Department of agriculture, forestry and fisheries. Republic of South Africa (2013).

[58] Komptech, Mobile Machines, Tech. rep., Komptech - Technology for a better environment (2006).

[59] Deere \& Company, MX5 Rotary cutter (accessed on 01-07-2014).

URL www.deere.com

[60] G. Ghekiere, A. Calus, A. Dumoulin, B. Mattheeuws, W. Platteau, T. P., J. Vanwalleghem, J. Velghe, B. Verstrynge, L. Willaert, Vergisting 


\section{Appendix A.2. Parameters} URL www . mansberendsen.nl URL www . machiels.com/

\section{Appendix A. Symbols}

\section{Appendix A.1. Indices}

c conversion type

f product type

$\mathrm{h}$ harvesting type

o bioenergy output type

$\mathrm{p}$ pre-treatment type

$r$ product type

s storage type

$\mathrm{t}$ time period

op boerderijschaal. Techniek, grondstoffen en eindproducten (Anaerobic digestion at farm scale. Technology, raw materials and finished products), Tech. rep., Provinciaal Onderzoeks- en Voorlichtingscentrum voor Land- en Tuinbouw (2007).

[61] Mans Berendsen VOF, Klepelmaaier EFG-175 - Technische gegevens (Flail mower EFG-175 - Technical data) (accessed on 7-10-2013).

62] S. Sokhansanj, J. Fenton, Cost benefit of biomass supply and pre-processing. A BIOCAP Research Integration Program Synthesis Paper, Tech. rep., University of British Columbia (2007).

63] ABDE Solutions, Bio-Energie Herk in Herk-de-Stad (Bio-energy in Herk-de-Stad) (accessed on 21-05-2014). URL www .abde.be/media/technieken/techniek2.pdf

[64] V. Fracescato, E. Anonini, Z. Bergomi, Wood fuels handbook, Tech. rep., AEBIOM (2008).

[65] L. Vandaele, Biomassa - vergisting - omzetten van biomassa in een energierijk gas (biomass - digestionn - converting biomass into an energyrich gas), Tech. rep., ODE-Vlaanderen vzw (2006).

[66] Schouten Machines, STH Panda/Faunus mower collectors (accessed on 01-07-2014). URL www.schouten.ws/producten.html

[67] Group Machiels, Bio Energy Lommel (accessed on 21-05-2014).

i location of biomass production site

$\mathrm{j}$ potential location to install a storage facility

$\mathrm{k}$ potential location to install a conversion facility
$A R E A_{i}^{f} \quad$ Area of product type $\mathrm{f}$ at biomass production site $\mathrm{i}$ (ha)
$D_{t}^{o} \quad$ Demand for bioenergy of type o in time period t (GJ)
$H B P^{f} \quad$ Harvestable biomass production of product type $\mathrm{f}\left(\right.$ ton $h a^{-1}$ )
$Q^{o} \quad$ Coefficient to define the allowed energy surplus as a function of the energy demand (-)
$\gamma_{H}^{f, r} \quad$ Transformation coefficient defining the change in product type due to harvest (-)
$\gamma_{N H}^{f, r} \quad$ Transformation coefficient defining the change in product type due to growth (non harvest) (-)
$\Delta^{s} \quad$ Product loss during storage type s (-)

\section{Appendix A.3. Decision variables}

$C_{c t}^{f k} \quad$ Quantity of product type f converted in the conversion facility with conversion technology c at location $\mathrm{k}$ in time period $\mathrm{t}$ (ton)

$E_{k t}^{c o} \quad$ Quantity of bioenergy of type o produced at conversion facility with technology c at location k (GJ)

$E_{\text {surplus } t}^{o} \quad$ Total quantity of surplus energy of type o generated in the supply chain in time period t (GJ)

$I_{c t}^{f k} \quad$ Inventory of product type $\mathrm{f}$ at conversion location $\mathrm{k}$ of conversion type $\mathrm{c}$ in time period $\mathrm{t}$ (ton)

$I_{j t}^{f s} \quad$ Inventory of product type $\mathrm{f}$ at storage location $\mathrm{j}$ of storage type $\mathrm{s}$ in time period $\mathrm{t}$ (ton)

$P_{j t}^{s p f} \quad$ Quantity of product type f produced after pre-treatment $\mathrm{p}$ at storage facility with storage type $\mathrm{s}$ at location $\mathrm{j}$ in time period $\mathrm{t}$ (ton) 
$P_{k t}^{c p f} \quad$ Quantity of product type f produced after pre-treatment $\mathrm{p}$ at conversion facility with conversion type $\mathrm{c}$ at location $\mathrm{k}$ in time period $\mathrm{t}$ (ton)

$s H_{i t}^{f} \quad$ Sum of product type $\mathrm{f}$ harvested at biomass production site $\mathrm{i}$ in time period $\mathrm{t}$ (ton)

$s N H_{i t}^{f} \quad$ Sum of product type f not harvested at biomass production site $\mathrm{i}$ in time period $\mathrm{t}$ (ton)

$S$ UPmax $x_{i t}^{f} \quad$ Maximum quantity of biomass of type $\mathrm{f}$ available at biomass production site i in time period $\mathrm{t}$ (ton)

$X_{c t}^{f k} \quad$ Quantity of product type $\mathrm{f}$ delivered at the conversion facility with conversion technology c at location $\mathrm{k}$ in time period $\mathrm{t}$ (ton)

$X_{c p t}^{f k} \quad$ Quantity of product type f pre-treated by pre-treatment type $\mathrm{p}$ at the conversion facility with conversion technology $\mathrm{c}$ at location $\mathrm{k}$ in time period $\mathrm{t}$ (ton)

$X_{i n j t}^{f s} \quad$ Quantity of product type $\mathrm{f}$ delivered at the storage facility of storage type $\mathrm{s}$ at location $\mathrm{j}$ in time period $\mathrm{t}$ (ton)

$X_{i n ~}^{f s p} \quad$ Quantity of product type f delivered at pre-treatment type $\mathrm{p}$ at the storage facility of storage type $\mathrm{s}$ $X_{\text {out } j t}^{f s}$ at location $\mathrm{j}$ in time period $\mathrm{t}$ (ton)

Quantity of product type f leaving storage facility of storage type $\mathrm{s}$ at location $\mathrm{j}$ in time period $\mathrm{t}$ (ton)

\section{Appendix B. Parameters used in the use case}

Table B.1: Attributes and their values describing the LIHD product types $(\mathrm{MC}=$ Mowing cycle, $\mathrm{RV}=$ grass from road verges, $\mathrm{MG}=\mathrm{grass}$ from mesotrophic grassland, TP2 = harvest in time period 2, TP4 = harvest in time period 4, TP24 = harvest in time period 2 as well as time period 4 )

\begin{tabular}{|c|c|c|c|c|}
\hline Product type & $\begin{array}{l}\text { Biomass production } \\
\quad\left(\mathrm{t} h a^{-1} M C^{-1}\right)\end{array}$ & $\begin{array}{l}\text { Biogas } \\
\left(m^{3} t^{-1}\right)\end{array}$ & $\begin{array}{c}\text { Moisture content } \\
(\%)\end{array}$ & $\begin{array}{l}\text { Particle size } \\
\qquad(\mathrm{mm})\end{array}$ \\
\hline RV - TP2 & $4.3^{c}$ & $100^{c}$ & $0.70^{c}$ & $20^{c}$ \\
\hline RV - TP4 & $3.6^{c}$ & $50^{c}$ & $0.70^{c}$ & $20^{c}$ \\
\hline RV - TP24 & $3.2^{c}$ & $100^{c}$ & $0.70^{c}$ & $20^{c}$ \\
\hline MG - TP2 & $3.8^{a}$ & $120^{b}$ & $0.65^{a}$ & $52^{a}$ \\
\hline MG - TP4 & $3.2^{a}$ & $60^{b}$ & $0.65^{a}$ & $40^{a}$ \\
\hline MG - TP24 & $2.7^{a}$ & $120^{b}$ & $0.65^{a}$ & $35^{a}$ \\
\hline Silage RV - TP2 & - & $92^{d}$ & $0.72^{e}$ & $20^{e}$ \\
\hline Silage RV - TP4 & - & $46^{d}$ & $0.72^{e}$ & $20^{e}$ \\
\hline Silage RV - TP24 & - & $92^{d}$ & $0.72^{e}$ & $20^{e}$ \\
\hline Silage MG - TP2 & - & $110^{d}$ & $0.72^{e}$ & $52^{e}$ \\
\hline Silage MG - TP4 & - & $55^{d}$ & $0.72^{e}$ & $40^{e}$ \\
\hline Silage MG - TP24 & - & $110^{d}$ & $0.72^{e}$ & $35^{e}$ \\
\hline Chopped silage MG - TP2 & - & $110^{d}$ & $0.72^{e}$ & $12^{e}$ \\
\hline Chopped silage MG - TP4 & - & $55^{d}$ & $0.72^{e}$ & $12^{e}$ \\
\hline Chopped silage MG - TP24 & - & $110^{d}$ & $0.72^{e}$ & $12^{e}$ \\
\hline Extra product & $\begin{array}{l}\text { Energy input } \\
\qquad\left(\mathrm{GJ} t^{-1}\right)\end{array}$ & $\begin{array}{l}\text { Biogas } \\
\left(m^{3} t^{-1}\right)\end{array}$ & $\begin{array}{c}\text { Moisture content } \\
(\%)\end{array}$ & \\
\hline Maize & $0.25^{j}$ & $170^{d}$ & $71^{f}$ & \\
\hline organic household waste & $0.1815^{j}$ & $100^{g}$ & $73^{g}$ & \\
\hline Pig slurry & $0.1696^{j}$ & $20^{i}$ & $91^{h}$ & \\
\hline \multicolumn{5}{|l|}{ References: } \\
\hline a Based on (38) & & & (28) & \\
\hline b $\quad(39)$ & & & $(50)$ & \\
\hline c Based on (51) & & & $(52)$ & \\
\hline d $\quad(53)$ & & & $(54)$ & \\
\hline e (46) & & & $(55)$ & \\
\hline
\end{tabular}




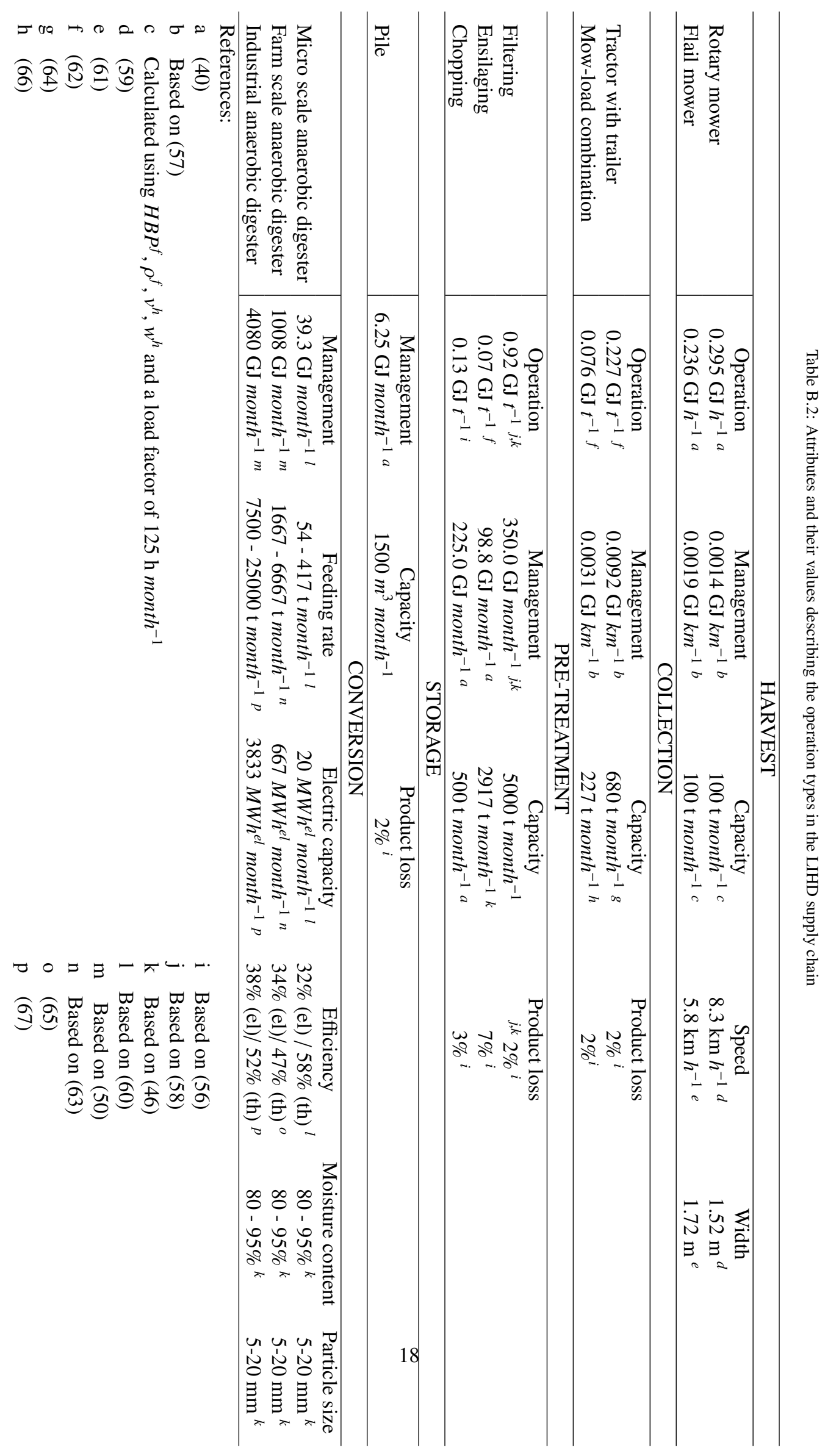

